\title{
BARRA HONDA (UPPER PALEOCENE - LOWER EOCENE) AND EL VIEJO (CAMPANIAN-MAASTRICHTIAN) CARBONATE PLATFORMS IN THE TEMPISQUE AREA (GUANACASTE, COSTA RICA)
}

\author{
Samuel Jaccard ${ }^{1}$, Marc Münster ${ }^{1}$, Peter O. Baumgartner ${ }^{1}$, \\ Claudia Baumgartner-Mora ${ }^{1}$ and Percy Denyer ${ }^{2}$ \\ 1) Institut de Géologie, Université de Lausanne, BFSH2, CH-1015 Lausanne, \\ Switzerland Peter.Baumgartner@igp.unil.ch \\ 2) Escuela Centroamericana de Geología, Univ. Costa Rica, Apdo. 214-2060 UCR, \\ Costa Rica
}

(Recibido 14/4/2000; Aceptado 31/8/00)

\begin{abstract}
In this preliminary paper we report on age, microfacies, microfossils and structural setting of platform limestones, that crop out in the Río Tempisque area (Guanacaste, Costa Rica). The limestones can be attributed to two distinct carbonate platform systems: 1. The El Viejo Platform, dated as late Campanian - Maastrichtian, which is represented by slope facies in the Cerros Ballena and Cebollín (near Filadelfia, Peninsula de Nicoya). 2. The Barra Honda Platform, of Upper Paleocene - Lower Eocene age, that extends from the classical outcrops at Cerro Barra Honda in the South, to the Palo Verde region in the North.

At Cerro Cebollín, carbonate-rich turbitites and mass flow deposits rest unconformably on basalts of the Nicoya Complex s. str. Pelagic limestone clasts with planktonic foraminifera, and abundant rudist fragments document a late Campanian - Maastrichtian age of the sequence. Basalt and serpentinite lithoclasts witness erosion of an oceanic basement, such as the Santa Elena Ultramafic Unit. The Cerro Cebollín sequence is interpreted as a slope deposit that received abundant material form shallow carbonate platforms of the El Viejo Formation that crops out in the northern Nicoya and Santa Elena Peninsulas.

At Cerro Barra Honda, Cerro Quebrada Honda and other classical outcrops of the Barra Honda Formation microfacies range from restricted to open marine. Most facies contain Ethelia alba a Squamariacean algae reported for the first time from Central America. Restricted micritic facies from Lomas las Pozas contain Thalmannita madrugaensis, a Rotaliid foraminifer, so far only known from the Paleocene of Cuba. In the Palo Verde area to the North, typical Barra Honda facies pass into high energy, open platform facies characterized by abundant red algae and larger foraminifera ranging from Late Paleocene to Early Eocene. Planktonic foraminifera such as Morozovella velascoensis allow to restrict the base of Barra Honda to the latest Paleocene.

In general, the Barra Honda Platform rests unconformably on deformed Late Cretaceous-Paleocene deep-water sediments. Its basal onsett is transgressive over subaerially altered rocks (Espíritu Santo) or progradational over open marine Late Paleocene sediments (Pochote). Reworked Late Cretaceous lithoclasts testify for lithification and (tectonic) exposure of the underlying rocks.

To the East of the Tempisque River, in the area of the Cerro Naranjo the emplacement of Barra Honda over intensely deformed detrital formations as young as middle Eocene may be attributed to gravity tectonics and/or a transpressive setting along longitudinal strike-slip faults that have been postulated along the Tempisque River.
\end{abstract}

RESUMEN: En este trabajo preliminar se reportan las edades, microfacies, microfósiles y la situación estructural de las calizas de plataforma que afloran en el área del río Tempisque (Guanacaste). Existen dos plataformas carbonatadas: el Viejo, de edad Campaniano Superior-Maastrichtiano, que está representada por facies de talud en los cerros Ballena y Cebollín y, la plataforma de Barra Honda, de edad Paleoceno Superior-Eoceno Inferior, que se extiende desde los afloramientos típicos, en el sur del área estudiada (cerros Barra Honda), hasta la región de Palo Verde al norte. En el cerro Cebollín, los basaltos del Complejo de Nicoya s.str están sobreyacidos disconformemente por depósitos turbidíticos y de mass. Clastos de caliza pelágica con foraminíferos planctónicos como globotruncanas (Globotruncanita elevata), macroforaminíferos (Sulcoperculina globosa, Sulcoperculina vermunti, Pseudorbitoides rutteni, Asterorbis, Nummuloculina, Proporocyclina) y abundantes fragmentos de rudistides atestiguan una edad del Campaniano Superior al Maastrichtiano para esta secuencia. Contenidos variables de clastos de basalto y de serpentinita 
documentan la erosión de un basamento ultramáfico, como la unidad Ultramáfica de Santa Elena. Interpretamos la secuencia de los cerros Ballena y Cebollín como depósitos de talud que fueron alimentados desde la plataforma somera de la Formación El Viejo, que aflora, tanto al norte de la península de Nicoya, como de la de Santa Elena.

En los cerros Barra Honda, Quebrada Honda y otros afloramientos clásicos de la Formación Barra Honda, observamos una variedad de microfacies que documentan paleoambientes de plataforma restringida hasta de plataforma abierta. Todas las facies se caracterizan por la presencia de algas rojas (coralinaceas) y de Ethelia alba, una alga de la familia Squariamaceae, característica del Paleoceno en las plataformas del Medio Oriente, que se reporta por primera vez en América Central. Ethelia alba aparentemente creció en las zonas de plataforma abierta y fue transportada en fragmentos hacia las zonas restringidas. Las facies micríticas contienen foraminíferos Rotalides, entre los cuales se destaca Thalmannita madrugaensis, que se conoce hasta ahora únicamente en el Paleoceno de Cuba, además formas de miliólidos y Alveolinides.

En la zona de Palo Verde (Fig. 5) las facies típicas de Barra Honda pasan a facies de alta energía, caracterizadas por la presencia de macroforaminíferos del Paleoceno Superior-Eoceno Inferior Ranikothalia catenula, Neodiscocyclina barkeri asociados a Ethelia alba .

En el cerro Espíritu Santo se observa la transgresión de la plataforma de Barra Honda sobre lutitas silíceas alteradas y cubiertas por un posible paleosuelo, estas lutitas descansan sobre basaltos. Las primeras capas de plataforma contienen cantos rodados y perforados típicos de la zona costera.

En el extremo sur de los afloramientos de Barra Honda, cerca de Pochote observamos una secuencia que documenta el retrabajo de clastos del Cretácico terminal en un ambiente de mar abierto, están caracterizados por abundantes foraminíferos planctónicos del Paleoceno Superior (Morozovella velascoensis) y Pentacrinites sp. (crinoideo de plataforma abierta). La secuencia pasa gradualmente a facies típicas de Barra Honda hacia el techo. Calizas de plataforma somera datados del Eoceno Inferior - Medio afloran como pequeños montículos en la región de la Laguna Jicote, en el noroeste de la zona estudiada. Se caracterizan por una microfacies rica en algas rojas (Coralinaceas) y macroforaminíferos (Discocyclina, Eoconuloides wellsi, Amphistegina). Por ahora no podemos interpretar el origen de estos afloramientos.

La plataforma Barra Honda sobreyace discordantemente a las formaciones deformadas del Cretácico Superior-Paleoceno, tanto al oeste del río Tempisque, como en la zona de Palo Verde. Al este del río Tempisque, en la zona del cerro Naranjo, el contacto basal de Barra Honda se caracteriza por la deformación semiplástica intensa de las formaciones detríticas subyacentes, las cuales pueden ser tan jóvenes como el Eoceno Medio. El emplazamiento de Barra Honda sobre estas formaciones puede ser atribuido a una compactación de las formaciones detritícas y un asentamiento de las calizas, aunque también puede ser un resultado de una situación transcompresiva, a lo largo de las fallas longitudinales que han sido señaladas a lo largo del Tempisque.

\section{INTRODUCTION}

The paleotectonics of Southern Central America are characterized by an assemblage of terranes, essentially of oceanic origin, that have been juxtaposed during the last 60 my along the East Pacific convergent plate margin. Carbonate platforms in such a setting are in general ephemerous, small scaled features, and their existence is often recorded only as resediments in deeper water sequences. In turn, the age, size, facies and the substrate of such platforms provide valuable information on the tectonic and/or magmatic events that rose oceanic basement or volcanic edifices into the photic zone.

Recent paleomagnetic data (Di Marco et al., 1995) suggest that the Santa Elena Peninsula and most of the outer Nicoya Peninsula are allochtonous relative to the Chorotega Terrane, which constituted the west- ern edge of the Caribbean Plate during the Late Cretaceous-Paleocene. Their allochtony is also corroborated by fundamental differences in age, lithology and tectonic structure between both units (Baumgartner, 1984; Baumgartner et al., 1984). Di Marco et al. (1995) indicated that the docking must have taken place during the Middle or Late Paleocene. This event certainly caused uplift in the studied area permitting the installation of a carbonate platform, such as Barra Honda.

Our study mainly focuses on the limestones outcropping in the Tempisque Basin (Fig. 1). This area is around 1000 kilometers square, located at the lower basin of the Tempisque River, near its mouth into the Nicoya Gulf. Geologically, this area is in a transpressive shear zone, originated by northwest right lateral faulting, which tectonically has controlled the area during the Tertiary. 


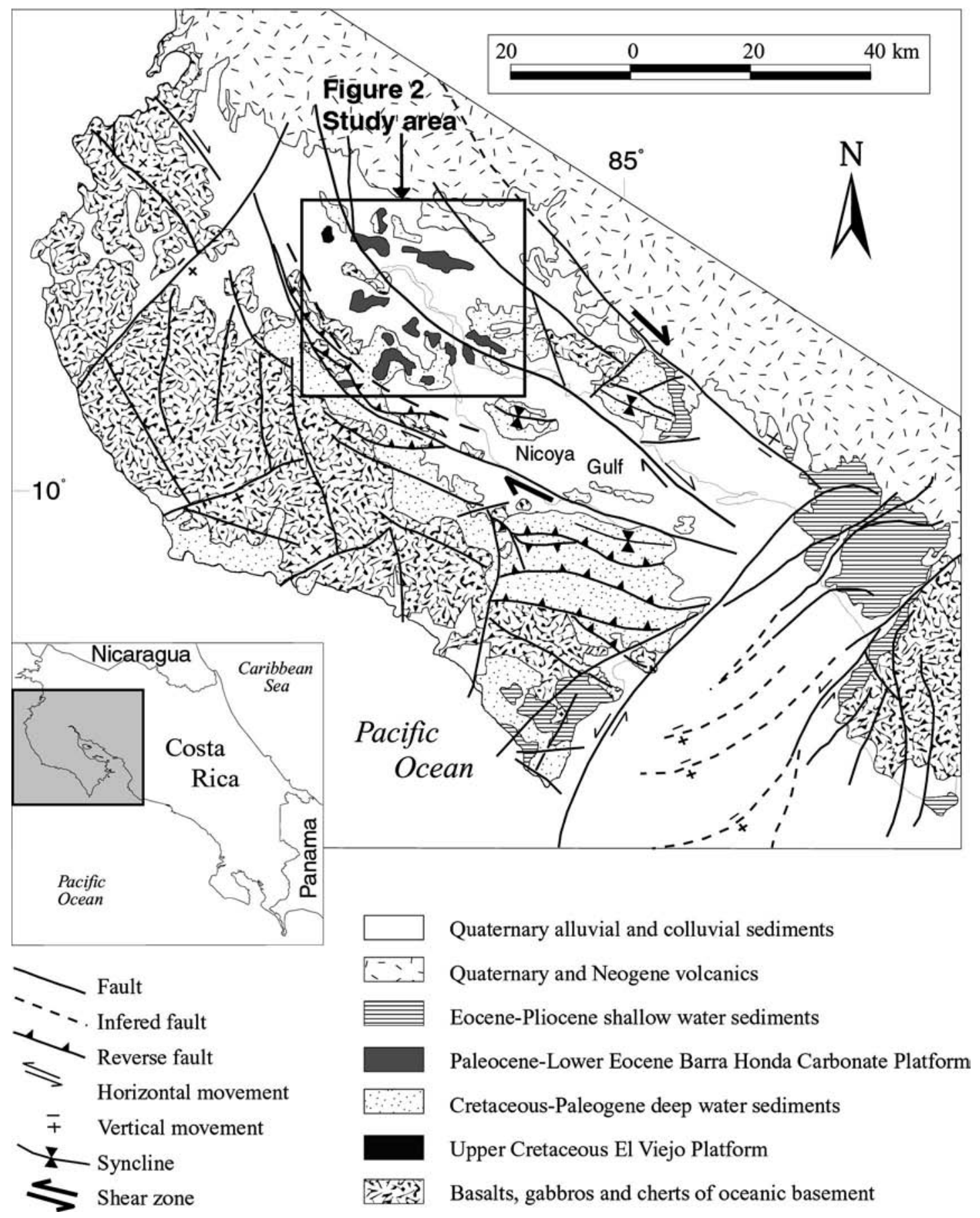

Fig. 1: Regional geologic setting of the studied area. Based on Burgois et al. (1984), M.I.E.M. (1982), Fernández (1997), Mora \& Baumgartner (1985), Tournon \& Alvarado (1997). 
The Barra Honda Formation (Dengo, 1962), micritic limestones of predominantly restricted platform origin (Mora, 1981), have not been dated directly nor correlated correctly with other facies in the area. Sprechmann et al. (1987) and Calvo (1987, 1998) correlated the Barra Honda limestones with the platform sequence of the El Viejo Formation (Schmidt-Effing, 1975), deposited during the Late Cretaceous. Neither Sprechmann et al. (1987) nor Calvo $(1987,1998)$ provided solid facts that would assess a Cretaceous depositional age for the Barra Honda limestones, generally considered devoid of agediagnostic fossils. Calvo (1987) assumed that the rudist facies characteristic of the El Viejo Formation was marginal to the restricted Barra Honda facies without providing any evidence of the lateral continuity between the two formations. Rivier (1983) suggested a Miocene depositional age for the Barra Honda limestones, evoking mainly structural considerations.

Only few data exist considering the limestones outcropping in the Palo Verde region. Calvo and Bolz (1991) described an Upper Paleocene-Lower Eocene transgressive sequence in the Cerro Espíritu Santo. Di Marco et al. (1995) mentions small Discocyclina, characteristic of a Paleocene-Early Eocene age, in micritic limestones of the Cerro Guayacán.

We present here an attempt to group the limestones of the Tempisque area and to propose a coherent depositional history in a rapidly evolving active margin environment. We report on new fossil associations and a new paleoenvironmental interpretation of the Late CretaceousEarly Eocene limestones of the area. Detailed field mapping allowed us to clarify the extension of the Barra Honda Platform. P. Denyer and P.O. Baumgartner carried out reconnaissance field work for this study in 1996. S. Jaccard and M. Münster did detailed mapping, sedimentological and structural analysis of every limestone outcrop of the area during 1999. C. BaumgartnerMora, is responsible for micropaleontology and microfacies interpretation in this study .

\section{THE CAMPANIAN - MAASTRICHTIAN EL VIEJO PLATFORM}

\author{
Geologic setting of the Cerro Matapalo \\ region
}

The Cerro Matapalo region (Fig. 2-3) lies about $20 \mathrm{~km}$ SE from Filadelfia. The major part of the outcrops is constituted by oceanic basalts, which we believe are part of the Nicoya Terrane basement. These basalts are unconformably overlain by a sequence of siliceous or calcareous hemipelagites and distal turbidites belonging to the Sabana Grande Formation (Campanian, Dengo, 1962). A Late Santonian-Early Campanian tectonic event that lead to the obduction of the Santa Elena Orogenic Complex and created an important, mostly submarine, relief (Azéma \& Tournon, 1980, Di Marco et al., 1995) that was subject to intense erosion. In the following, we report on redeposited limestones and volcanoclastic turbidites that crop out in the Cerro Cebollín and Cerro Ballena.

\section{Cerros Cebollín and Ballena}

Cerro Cebollín and Cerro Ballena (Fig. 4), the basaltic basement is stratigraphically overlain by coarse-grained rudist-bearing mass-flow sequences (Fig. 5). The bivalves are almost intact, attesting a short transport distance, and are often biocorroded. Rocks also contain number of larger benthic foraminifera: Sulcoperculina globosa, Sulcoperculina vermunti, Pseudorbitoides rutteni, Asterorbis, Nummuloculina, Proporocyclina (Pl. 1) and various red and green algae, attesting a Campanian-Maastrichtian depositional age. The basaltic basement is locally overlain by finegrained basaltic material resulting from the alteration of the pillow-lavas. The approximately $20 \mathrm{~m}$ thick rudist-bearing mass-flow deposits are followed by pebbly-mudstone layers.

The uppermost part of the sequence is constituted by a succession of thin marly layers representing a minimum thickness of $40 \mathrm{~m}$. The 




Fig. 2: Geographic map of the Tempisque River Basin with the 3 main study areas and geographic names used in the text. Note location of Figs. 3-9.

proportion between detritic and carbonated fractions varies from one bed to another. They contain lots of pelagic and volcanic lithoclasts, occasionally larger than $10 \mathrm{~mm}$. The pelagic clasts (Pl. 1-1) are rich in large benthic and planktonic foraminifera such as Globotruncanita elevata (Pl. 2-2), which also are present in the matrix, suggesting a Late Campanian-Maastrichtian depositional age. The igneous lithoclasts include serpentinite fragments. The surveyed rocks also contain rudists (Pl. 1-3), echinoderms, and different types of algae (Solenoporacea, Corallinacea). Bioclasts are generally broken and perforated indicating their reworking in the photic zone. This thick turbiditic sequence is followed by other coarse-grained rudist-bearing mass-flow deposits, similar to those cropping out at the bottom of the sequence.

These deposits provide valuable clues concerning the regional paleogeographic 




Fig. 3: Geologic map of the Cerro Cebollín - Cerro Matapalo area. Outcrops are restricted to isolated hills surrounded by alluvial plains (left in white). Note location of Fig. 4.

interpretation during the Late Cretaceous. Rudists must have originated from the carbonate platform constituting the El Viejo Formation (Schmidt-Effing, 1975). This platform expanded directly on the Santa Elena Orogenic Complex during the Late Cretaceous (Late Campanian-Maastrichtian) (Azéma \& Tournon, 1980). This Complex formed the structurally most elevated part on the Terrane. Igneous lithoclasts, mainly serpentinite, reflect the alteration of this ophiolitic complex. The reworked carbonate facies closely resemble those exposed in the El Viejo Formation, but are distinct from Late Cretaceous facies overlying the Tortugal Ultramafic Suite (Alvarado et al., 1997). Therefore, we interpret the studied sequences at Cerro Cebollín as slope facies of the El Viejo Platform. The thickness of these turbiditic sequences clearly indicates that this platform was well-developed and that part of the underlying ophiolitic basement was exposed to erosion, suggesting that the 


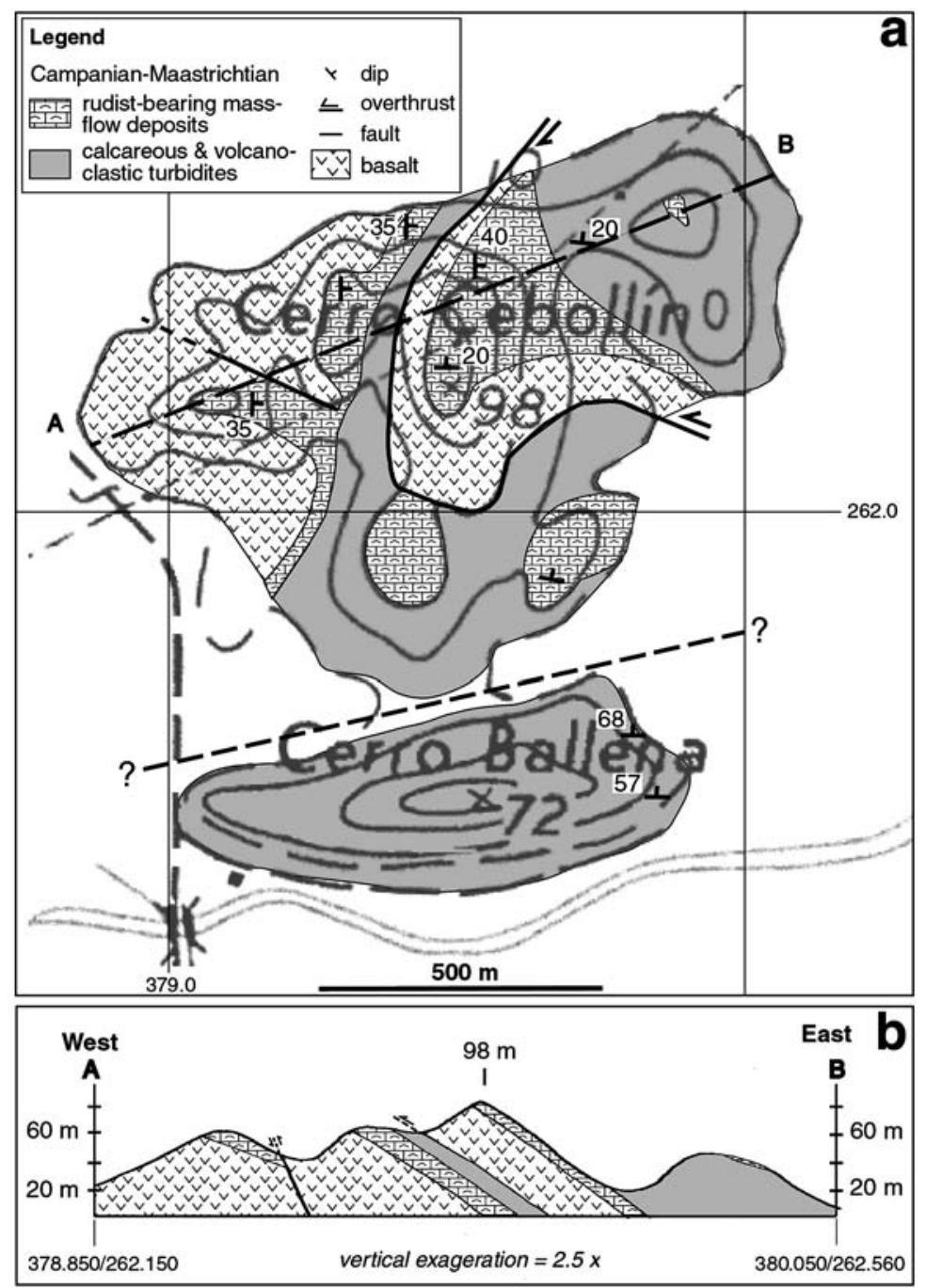

Fig. 4: Geologic map (a) and cross section (b) of the Cerros Ballena and Cebollín.

Complex underwent a significant uplift during this period.

\section{Structure}

The location of the fault and the overthrust (Fig. 4) affecting the basalts as well as the detritic series in the Cerro Cebollín is based on stratigraphic observations. The overthrust has a deca- metric vertical throw. The southern, nothwest southeast trending fault probably underwent a significant dextral strike-slip motion. The overthrust marks the contact between the turbiditic series and the basalts on the eastern hillside of the Cerro Cebollín. It seems to have an hectometric relative displacement. These structures could be related to the dextral transverse fault system affecting the Tempisque Basin (Fig. 1). 


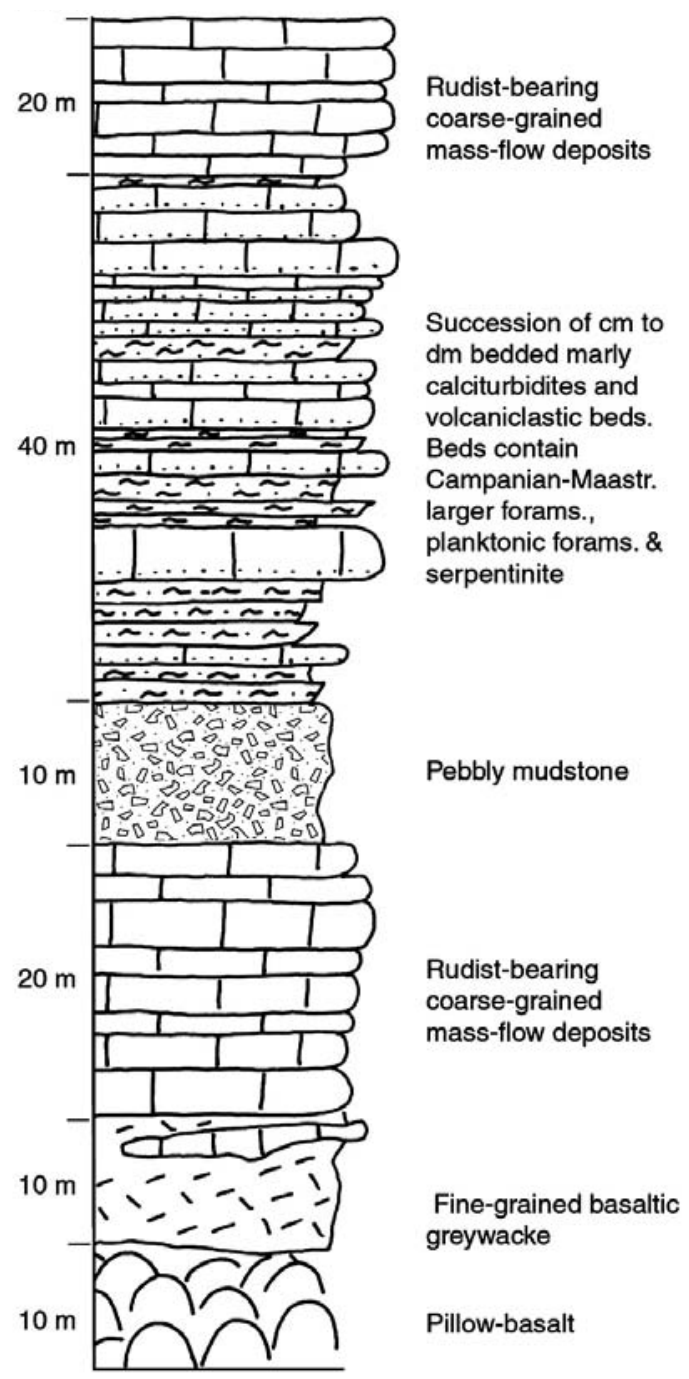

Fig. 5. Stratigraphic column of the Cerros Ballena and Cebollín, Campanian-Maastrichtian carbonate slope facies, coord: 378.0/262.0.

\section{THE PALEOCENE - EOCENE BARRA HONDA PLATFORM}

\section{Geological setting of the Palo Verde Region}

The Palo Verde Region (Fig. 2- 6) includes the area between the Río Tempisque and the Río Bebedero, in the north-east of the Tempisque
Basin. Scattered hills are systematically crowned by limestone outcrops that overlie the Sabana Grande turbiditic Formation. Most of the studied area is part of the Palo Verde National Park.

All limestone in this area appear to be of Paleocene-Early Eocene age (see below), but are of a wide variety of microfacies. We divided this area into three major parts: the Cerro Espíritu Santo, the Cerro Alto Viejo and Cerros la Cueva del Tigre area, and the southern part, to which the Cerros Guayacán and Fila Catalina belong.

\section{Espíritu Santo}

The Cerro Espíritu Santo (Fig. 7) is the only place where there is clearly no tectonic discontinuity between the limestones and the underlying detrital sediments. An outcrop near the top of the hill (coord.: 388.1/263.1) shows the evidence of a Late Paleocene-earliest Eocene transgression of the Barra Honda carbonate platform on deeply altered Sabana Grande-type sediments (Fig. 8).

The western base of the Cerro Espíritu Santo consists of basalts, overlain by $40-80 \mathrm{~m}$ of Sabana Grande turbidites (Fig. 7). At the top of the sequence, the detritic layers are very altered and are covered by a thin centimetric brownish layer interpreted as a paleosoil (see also Di Marco et al., 1995). The first calcareous elements appear on top of this layer (Fig. 8), as well rounded, encrusted and bored limestone cobbles (Di Marco et al. 1995), showing a typical beach environment. These consist of mudstones and wackestones containing red algae and gastropods. The encrustation is made by Melobesiae (encrusting red algae) and a Squamariacean algae, Ethelia alba, also present in the matrix (see discussion below).

One meter higher in the sequence, the facies vary laterally and are distributed as lenses. We found some Discocyclina-grainstones and some oolithic- and Amphisteginid and Ranikothalia limestones, in which cross-beddings could be observed.

All these facies are characteristic of a shallow-water, high-energy environment representing the platform edge. Thus, the Cerro Espíritu Santo is the relic of the transgression and 
setting up of a limestone platform during the Late Paleocene-Early Eocene.

\section{Cerro Alto Viejo and Cerros La Cueva del Tigre}

Along the crest of the Cerros Alto Viejo and La Cueva del Tigre, we observed many, different facies, each of which crops out as a single coherent block of about $10 \mathrm{~m}$ width and has no continuity with the others. There are large foraminifera-packstones and wackestones, sedimentary calcareous microbreccias, Miliolidaeand red algal-wackestones, and even a Lower Paleocene pelagic lime-mudstone. In various blocks of different facies we found Morozovella velascoensis (Pl. 3-2), which is restricted to the Upper Paleocene.

The variety of the facies as well as their incoherent juxtaposition cannot yet be explained

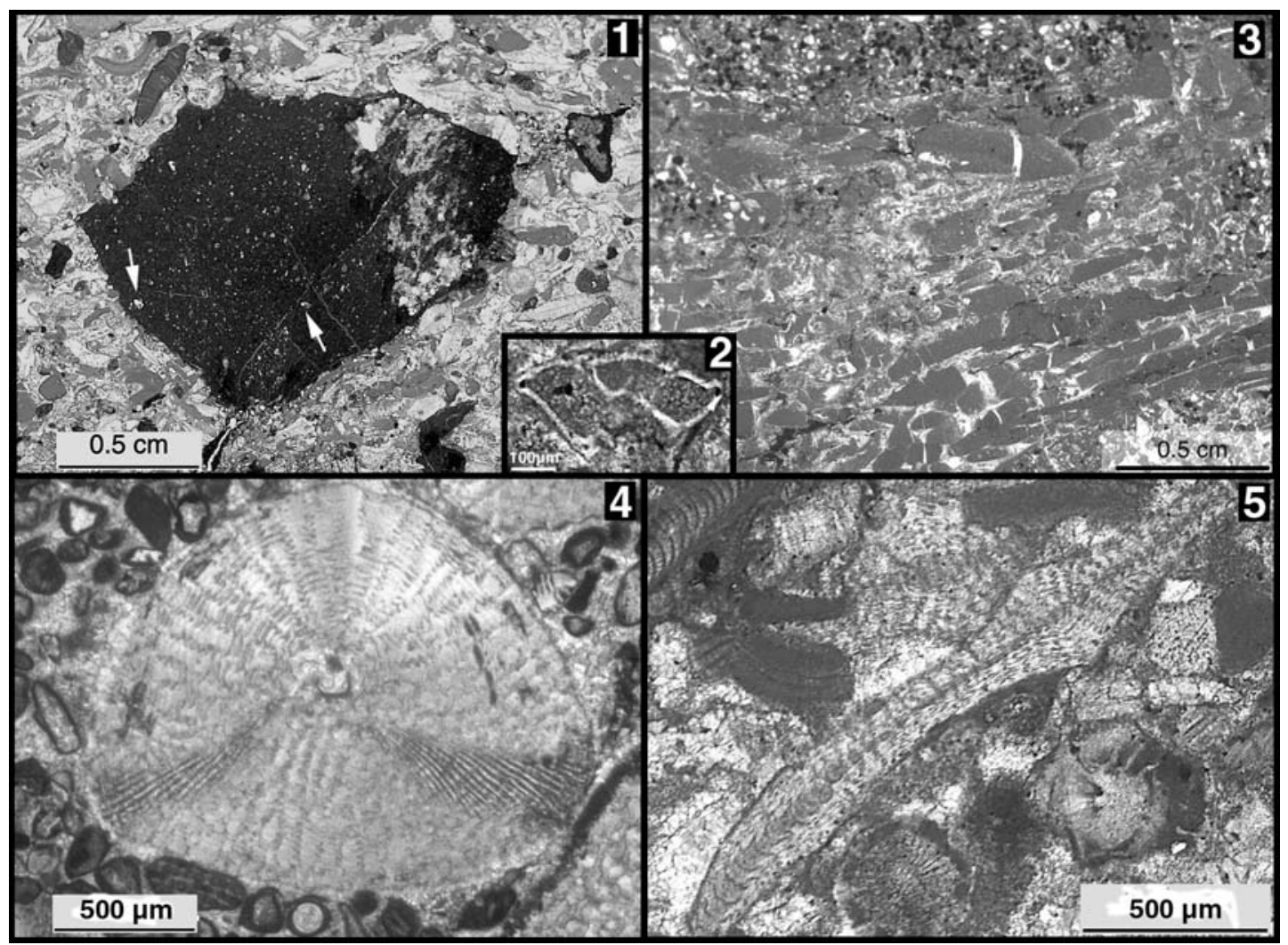

Plate 1: Campanian-Maastrichtian microfacies and age diagnostic microfossils from Cerros Ballena and Cebollín, interpreted as slope facies of the El Viejo Carbonate Platform.

1-1. Bioclastic packstone principally made of larger foraminifera (Sulcoperculina sp. Proporocyclina sp.) and red algae (Coralinaceae) containing a cm-sized clast of pelagic limestone. The clast yields Campanian-Maastrichtian planctonic foraminifera (arrows). Sample from Cerro Ballena (coord.: 379,9/261,5).

1-2. Globotruncanita elevata of Late Campanian age from a pelagic limestone clast in mass flow deposits, Cerro Ballena (coord.: 379,9/261,5).

1-3. Rudist fragment with the characteristic rectangular mesh structure of the shell now recrystallized as calcite cement. Original pore space is now filled with dark micrite. Sample in mass flow deposit, Cerro Cebollín (coord.: 379,6/262,4).

1-4. Pseudorbitoides rutteni Bronnimann in an oolitic grainstone. Campanian-Maastrichtian mass flow deposits from Cerro Cebollín (coord.: 379,5/262,5).

1-5. Asterorbis sp. cf. A. macei Palmer, and articulate Coralinacean red algae in a bioclastic packstone. Campanian-Maastrichtian mass flow deposits. Cerro Cebollín (coord.: 379.7/261.7). 




Plate 2: Paleocene (and reworked Late Cretaceous) microfacies of the Barra Honda Platform.

2-1. Lithoclastic wackestone to packstone near the base of the Pochote section (Fig. 8) (coord.: 395.6/236.6). Bored and biocorroded clasts of pelagic limestone contain Late Cretaceous Globotruncanids (arrow). The bioclastic matrix of the rock contains Paleocene planctonic and larger benthic foraminifera, algae, and crinoids such as Pentacrinite sp. (open marine genus).

2-2. Globotruncana ventricosa, ranging from Late Campanian to Early Maastrichtian, from a reworked clast in Paleocene sediments at Pochote (coord.: 395.6/236.6).

2-3. Bioclastic packstone containing mud lumps, larger foraminifera (Amphisteginids) and Corallinacean red algae. Good sorting and macroscopic cross-lamination are indicative of wave-driven winnowing. Cerro Espíritu Santo (coord.: 388.2/262.8).

2-4. Algal-hydrozoan boundstone. To the left a large fragment of a Solenoporacean. The element in the center is a Hydrozoan, the clasts are bound by encrusting Melobesiae and the Squamariacean algae Ethelia alba (white seams). Cerro Quebrada Honda (coord.: 389.7/243.6).

2-5. Bafflestone with large rhodoliths (at bottom) that are made of Melobesian red algae (dark), and encrusted by Ethelia alba, a Squamariacean algae, typical for the Barra Honda Platform, that is apparently in growth position. Cavities in this boundstone are filled with bioclastic packstone made of Corallinacean red algae, Ranikothalia sp., Nummulites and some planctonic foraminifera. A few metres above the transgression, Cerro Espíritu Santo (coord.: 388.1/263.1).

in a satisfactory way. The facies that represent distinct paleoenvironments could have become juxtaposed by dismembering of the platform due to compaction of the underlying soft sediments, probably during earthquakes. This interpretation is supported by the presence of siliceous veins proceeding from the underlying detrital sediments, which often penetrate the limestone blocks. However, because of similar age ranges of the different facies we think that they belong to the same platform.

\section{South-eastern outcrops (Cerro Guayacán, Fila Catalina and related outcrops)}

The variety of facies of the south-eastern outcrops (Fig. 6) is much less important than the 
in the Cerros Alto Viejo and La Cueva del Tigre. They are mostly red algal- and echinodermwackestones, with abundant micrite. At the site called Mirador La Roca (coord.: 390.5/258.5), we found lots of well developed rodoliths, as well as Discocyclinids (Neodiscocyclina barkeri) from the Upper Paleocene-Lower Eocene (Caudri, 1975).

\section{Remarks on Ethelia}

Many limestones are rich in the Squamariacean alga Ethelia alba (Pfender 1936), (Pl. 2-5 Pl. 3-1) that grew encrusting rhodoliths and any other hard bioclastic substrate is typical of Paleocene algal platforms. Although its total range is given as Barremian to Eocene (Massieux and Denizot 1964, Praturlon 1966), most illustrated specimens come from Paleocene limestones of Southern Europe and the Middle East, in America it was reported from the Lower-Eocene of Venezuela (Pfender \& Schneegans, 1949). We report
Ethelia alba for the first time from Costa Rica (and probably from Central America). It is characteristic of the various Barra Honda facies. It has not been observed in any Late Cretaceous facies assemblage of Costa Rica. Ethelia alba is found as crusts in situ made of multiple thalli (Pl. 2-5) in moderate to high energy open platform facies, but also as fragments in micritic, restricted platform facies. Apparently, individual thalli got easily stripped off the crusts and transported by storms into the more protected areas of the platform.

\section{Synthesis of the Palo Verde Region}

Our structural, sedimentological and micropaleontological analysis of the Palo Verde region demonstrates that a variety of facies in these different areas share the same Paleocene to Early Eocene age. Every sample is typified by the presence of Ethelia alba. We found this algae in "living position" at the Espíritu Santo (Pl. 25), together with Ranikothalia catenula sensu

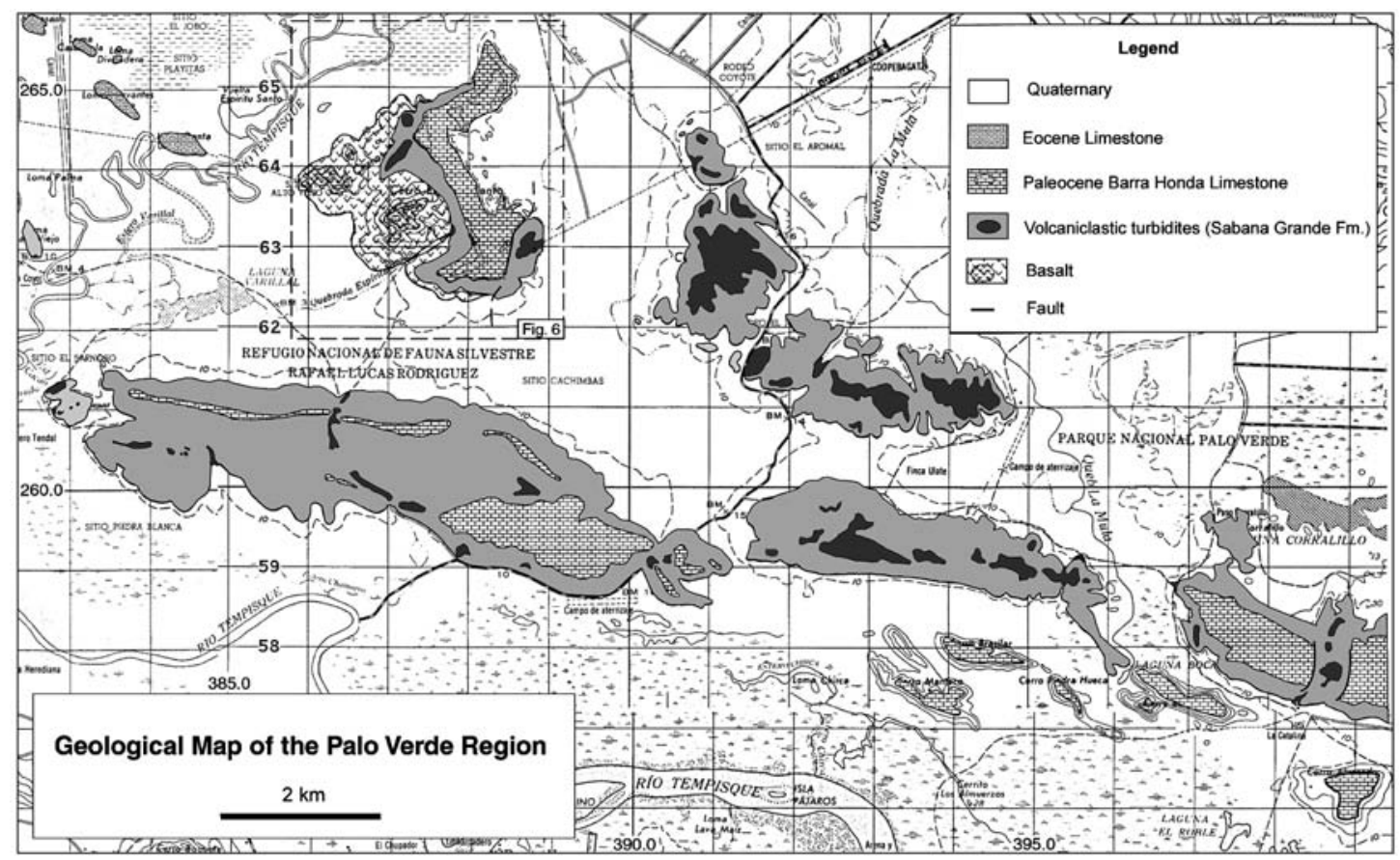

Fig. 6: Geologic map of the Palo Verde region. Outcrops are limited to a series of hills. The alluvial plain is shown with the information of the topographic map. Note location of Fig. 7 
Caudri 1990 (Pl. 3-4). We propose that there is only one platform in the whole region. Its transgressive base is evidenced in the Espíritu Santo section (Fig. 8). The Cerro Alto Viejo and Cerros La Cueva del Tigre crest could be the remnant of a collapsed rim of the platform, setting blocks of different facies side by side.

\section{Bajo Tempisque}

The limestones of the Bajo Tempisque are the classical Barra Honda outcrops lying west of the Río Tempisque, as well as those around Puerto Níspero and Peña Blanca, east of the river. In this region they rest on the Campanian-Paleocene Rivas Formation. Until now no direct dating has been performed in this area, because of the lack of adequate micropaleontological data.

The predominant facies are white algaland echinoderm-rich wackestones, whose matricial contents can be variable. In some places the rock is made of pure micrite, and can be strongly recristallized. Miliolids, gastropods, as well as ostracods are quite common. The Squamariacean alga Ethelia alba (Pl. 3-1) is also present in quite every sample and is sometimes more than two centimeters large.



Fig. 7: Geologic map of the Cerro Espíritu Santo. Actual outcrops are represented by denser patterns. 




Fig. 8: Stratigraphic column representing the unconformable, transgressive base of the Barra Honda Platform as exposed in the Cerro Espíritu Santo. Coord. 388.1/263.1.

The facies variations are at a very small scale (metric to decametric), and seem to be erratic. They range from a restricted to an open platform shallow-water environment. The platform had probably a complex, small scale paleogeography with a network of current channels, small ponds and numerous algal patch reefs.

On the Cerro Coralillo, we found besides numerous Miliolids, Alveolinids such as Praealveolina (Pl. 3-3). At Lomas las Pozas we discovered Morozovella sp. from the Upper Paleocene-Lower Eocene. At the same locality we also found Thalmannita madrugaensis (Cushman and Bermudez) a rotaliid that is so far known only from the Paleocene of Cuba (Bermudez, 1978).
North of Puerto Níspero (coord.: 401.1/244.3), Aguilar \& Denyer (in press) described a Paleogene coral reef with m-sized coral colonies in living position scleractinia: Euphyllia nov. sp., unique in the whole Tempisque Basin.

At Pochote (coord.: 395.6/236.6) (Fig. 2 ), south of the Cerros Copal, we studied a sequence which shows the reworking of pelagic Cretaceous limestones in an Upper Paleocene-Lower Eocene foreslope matrix at its base, and grades upsection into typical Barra Honda facies (Fig. 9). The serie begins with a polymict breccia, containing pelagic limestones and Barra Honda-type red algae white packstone clasts. The matrix consists of an encrinitic packstone, containing many different planctonic foraminifera and red algae. It disappears slowly near the middle of the serie. We found some Morozovella sp. and a Pseudohastigerina in it. Ethelia alba (Pl. 3-1) is present in both the matrix and the platform clasts. The pelagic lithoclasts are the largest and the most abundant at the base; higher in the sequence, they become smaller and finally disappear, meanwhile the opposite happens to the platform type clasts. At the top of the serie, only platform clasts remain and there is no more open-marine influence.

The angular pelagic clasts (Pl. 2-1) contain planktonic foraminifera from the Upper Cretaceous (Globotruncana ventricosa, Pl. 22) and some of them are bored by bivalves. These limestones have probably been uplifted and lithified before being eroded, bored and redeposited. There are also autochthonous resedimented clasts (intraclasts) derived from the surrounding rock itself. All this is in agreement with a fore-slope environment, which collects fragments of a platform in an openmarine environment. Fracturing of slightly indurated platform sediments could have occurred during earthquakes or related events. Fragments were transported by submarine currents downslope.

The Pochote outcrop seems to be the remnant of the Upper Paleocene-Lower Eocene progradation of the Barra Honda Platform, 


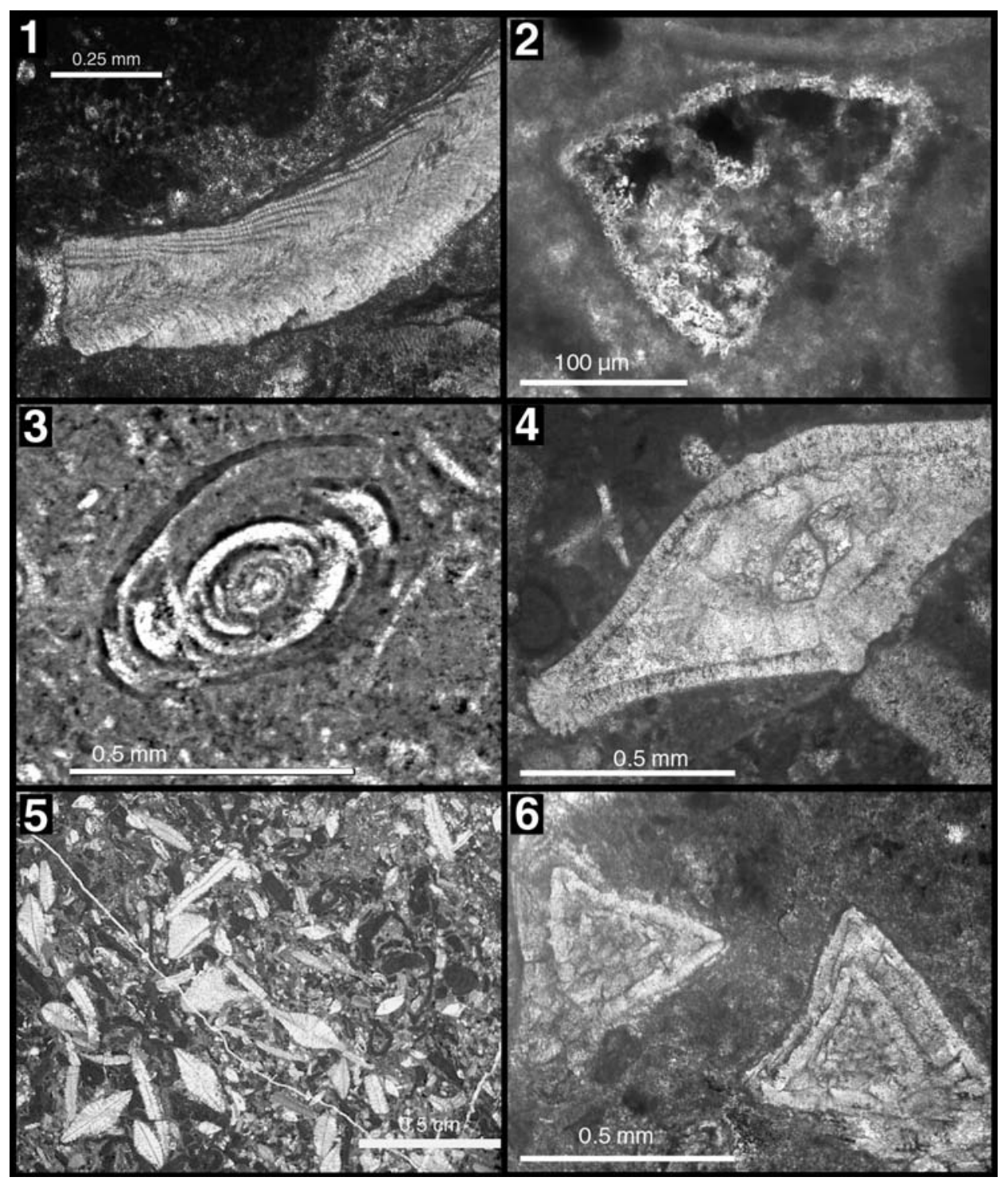

Plate 3: Paleocene age and facies diagnostic microfossils of the Barra Honda Platform.

3-1. Detailed structure of Ethelia alba, a Squamariacean algae, very common in all outcrops of the Barra Honda Limestone. Note the thick (lower) layer with wedge-shaped structure and the thin (upper) layer with flat rhodophycean structure. Pochote (coord.: 395.6/236.6).

3-2. Morozovella velascoensis, restricted to the latest Paleocene, Cerro Alto Viejo (coord.: 385.8/260.9). Note: scale of illustration is more than twice as large than Plates 1-2 and 2-2. Through superficially similar in shape, Paleocene Morozovellae are less than half the size of Campanian-Maastrichtian Globotruncanids.

3-3. Praeoalveolina sp., a Paleocene porcelanaceous foraminifer typical of the restricted micritic Barra Honda facies. Cerro Corralillo (coord.: 388.4/241.8).

3-4. Ranikothalia catenula, a larger foraminifer restricted to the Late Paleocene-Early Eocene. Cerro Espíritu Santo (coord.: 388.1/263.1).

3-5. Bioclastic packstone made of Corallinaceans and Middle Eocene larger foraminifera such as Discocyclina sp. and Nummulitids. Lomas El Jicote (coord.: 381.8/266.2).

3-6. Eoconoloides wellsi, of Lower to Middle Eocene age. Laguna Jicote (coord.: 381.8/266.2). 
which probably appeared after the uplift that exposed Upper Cretaceous pelagic limestones to erosion. Although the Pochote outcrops are not directly connected to a major limestone body, its geographic position, sedimentology and age matches correctly with the Barra Honda Platform history.

\section{Laguna Jicote}

The wackestones outcropping near the Lomas el Jicote (Fig. 3) rest unconformably on the Sabana Grande turbiditic series. These limestones contain a number of age-diagnostic Discocyclinids (Pl. 3-5), such as Neodiscocyclina bullbrooki (Caudri) and Amphisteginids as Eoconuloides cf. wellsi (Pl. 3-6) indicating an Early-Middle Eocene depositional age. The samples are matrix-supported and contain numerous echinoderm fragments and various red algae types. Their emplacement history is still enigmatic. Their morphology and structural position privilege an olistolithic deposition. These limestones only cover a restricted area and might represent the top of the Barra Honda Platform. This speculative hypothesis may only be confirmed by further work.

\section{DISCUSSION}

\section{Cerros Cebollín and Ballena}

Because of its Late Cretaceous age and facies associations, the carbonate-rich slope deposits at Cerros Cebollín and Ballena cannot be slope facies of the Paleocene Barra Honda Platform as sugested by Calvo (1987, 1998). For instance, Ethelia alba, omnipresent in the Barra Honda Limestones has not been found at Cebollín and Ballena. On the other hand, the redeposited matrerial compares very well with rocks attributed to the El Viejo Formation, exposed in Northern Nicoya and Santa Elena. Baumgartner et al. (1984) described a sequence with very similar, but more proximal facies in the southeastern cliffs of Bahía Santa Elena, that is overlain by Late Campanian-Maastrichtian pelagic and then turbiditic sediments.

\section{Relationship of the Barra Honda Platform with underlying rocks}

In general, west of the Tempisque River, and in the Palo Verde area the Barra Honda Limestones unconformably overlie Campanian to Paleocene pelagic-hemipelagic and turbiditic formations commonly attributed to the Sabana Grande and Rivas Formations, respectively (Dengo, 1962). The basal onset of the formation is clearly transgressive over deeply altered, probably subaerially exposed Rivas at Cerro Espíritu Santo, the northernmost outcrops of Barra Honda. At the southern edge of Barra Honda outcrops, near Pochote, the onset of the formation is regressive or progradational over open marine Late Paleocene calcarenites. Reworked and bored Late Cretaceous lithoclasts are very common in the basal outcrops of Barra Honda. They testify for lithification and (tectonic) exposure of the underlying formations, prior to the sedimentary onset of Barra Honda. Hence, the Barra Honda Platform can be considered as a mesoautochthonous (i. e. formed between two tectonic events) sequence that unconformably overlies the deformed Sabana Grande and Rivas Formations. Calvo (1987, 1998), Sprechmann et al. (1987, 1994) assumed a Late Cretaceous age for Barra Honda and implied a tectonic or gravitative emplacement of the whole platform over the underlying rocks. We cannot confirm a general allocthony of Barra Honda. However, where basal contents are exposed they are generally tectonized and the underlying poorly lithified detrital rocks are squeezed into the fractured and karstified limestones. These observations apply for the southernmost outcrops, east of the Tempisque River and for the Quarry at Cerro Calera, East of the town Nicoya (Fig. 2) where we saw striation and deformation at the base of the limestones. It seems obvious that the contact between limestones and turbidites has undergone relative displacement: small scale overthrust indications (shear zones in the detrital sediments, small decametric overthrusts) can be observed quite often.

We also found some tectonic breccias, which lie mostly at the base of the limestones, but which can also sometimes be intraformational. On 


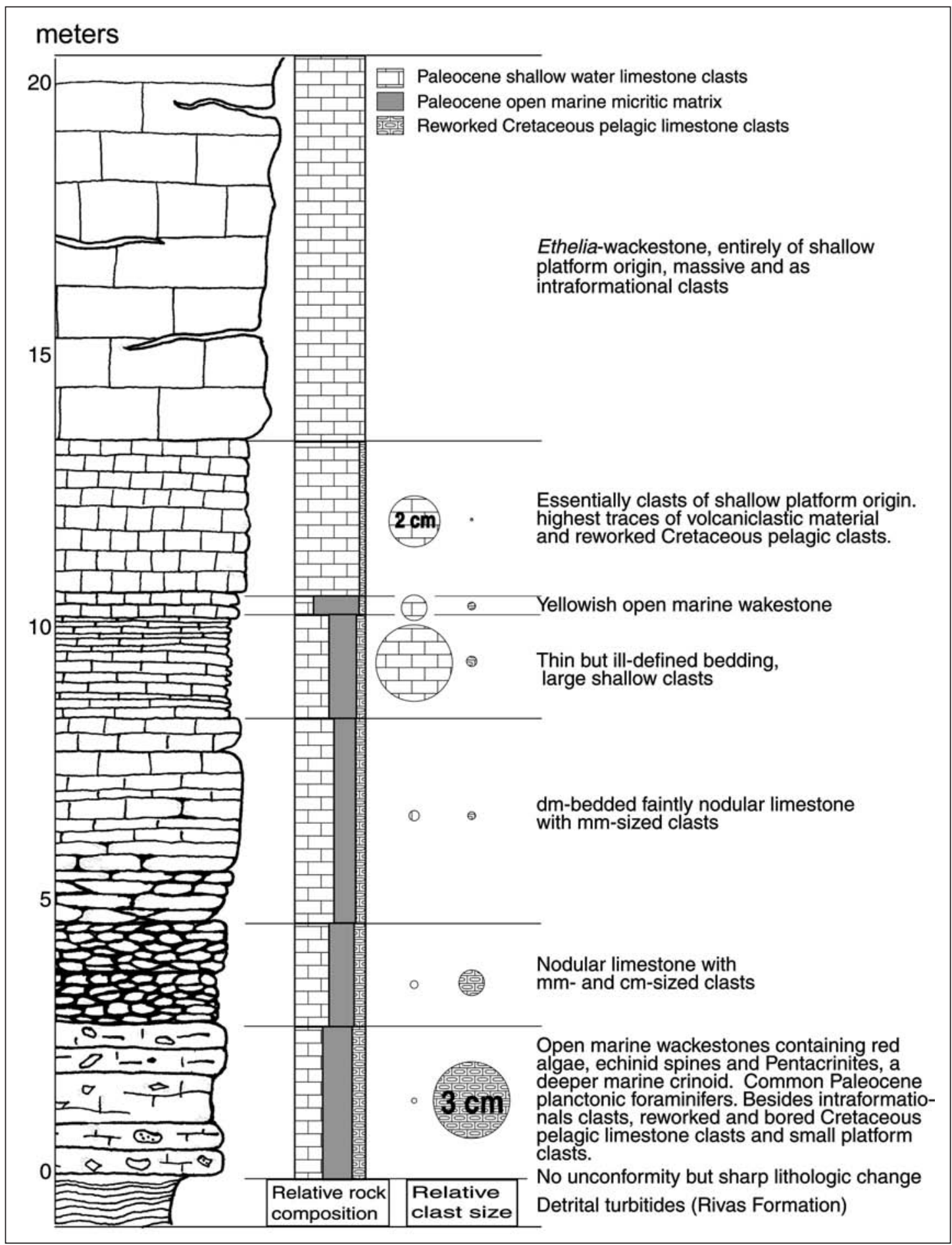

Fig. 9: Stratigraphic column studied near Pochote (for location see Fig. 2), one of the southernmost outcrops of the Barra Honda Platform. The measured section illustrates the progradational passage from open marine calcarenites to the restricted Barra Honda Platform. Coord. 395.6/236.6 
the eastern side of the Tempisque, micropaleontologic dating seems to indicate an Eocene age for the detrital sediments forming the substrate of Barra Honda (Rivier 1981), implying a tectonic emplacement of the older limestones over younger detrital sediments. However, the sediments which directly underlie the limestones have not been dated and the precise tectonic relationship between the two units has to be examined.

If the sediments underlying the limestones were of Paleocene age, Barra Honda would follow stratigraphically. If the underlying sediments were Eocene in age, we would consider an eastward post-Eocene overthrust of the Barra Honda Platform over these sediments. This could have occurred in the context of the transpressive shear zone shown in figure 1.

\section{CONCLUSIONS}

We can divide the limestones of the Tempisque Basin in two clearly distinct carbonate platform systems:

1- The El Viejo Platform, dated as late Campanian-Maastrichtian by abundant rudistids and larger benthic and planctonic foraminifera. It is represented in the Cerros Ballena and Cebollín. The turbidites and mass flow deposits at this locality are interpreted as slope deposits that received abundant material from shallow carbonate platforms of the El Viejo Formation that crops out in the northern Nicoya and Santa Elena Peninsulas. Therefore, this area can be attributed to the Nicoya Terrane as defined by $\mathrm{Di}$ Marco et al. (1995).

2- The Barra Honda Platform, dated as Upper Paleocene-Lower Eocene by larger benthic, and planctonic foraminifera. The observation of Morozovella velascoensis allows restriction at least of the base of the Barra Honda Platform to the latest Paleocene (P4 to lowermost P6). Today, the platform extends from the classical outcrops at Cerro Barra Honda in the South, to the Palo Verde region in the North. At Cerro Espíritu Santo, the latest Paleocene landward transgression of the platform is exposed. At Pochote in the South, we observed evidence of seaward progradation of the platform over open marine carbonates during the latest Paleocene. Small scaled lateral facies changes between moderate- to high energy and restricted microfacies suggest a relatively small platform covered by numerous algal patch reefs that are separated by current-swept channels. The common feature of these microfacies is the presence of red algae and Ethelia alba, a Squamariacean algae that seems to have grown in the high energy paleoenvironment and was transported as fragments into the restricted platform environment. We believe that the docking of the Nicoya Terrane during the Late Paleocene could have caused the necessary uplift to create a shallow substrate for the initiation of the Barra Honda Platform deposition.

\section{ACKNOWLEDGEMENTS}

We are very thankful to Lucas Hottinger who verified our micropaleontological determinations and to make valuable suggestions to the age and facies interpretation given in this work.

The field work of P.O.B. and P. D. was carried out in the frame of Projects No. 2000039545.93 and 2000-49401.96 of the Swiss National Science Foundation. Without this financial support, field work in Costa Rica would have been impossible.

We gratefully acknowledge the Ministerio del Ambiente y Energía (MINAE) of Costa Rica (Mr. Javier Guevarra), who extended permits for research and collection of samples in the Palo Verde and Barra Honda National Parks. We acknowledge the logistical support provided by The Escuela Centroamericana de Geología and the project 11390-071 of the Universidad de Costa Rica. 


\section{REFERENCES}

AGUILAR, T. \& DENYER, P., 2001 [in press]. Una especie nueva de Euphyllia (Scleractinia: Caryphylliidae) en las calizas de Barra Honda (Paleóseno), Costa Rica. - Rev. Biol. Tropical, 49 Supl. 2:53-59.

ALVARADO, G.E., DENYER, P.C. \& SINTON, C.W., 1997: The 89 Ma Tortugal komatiitic suite, Costa Rica: implications for a common geological origin of the Caribbean and Eastern Pacific region from a mantle plume. - Geology, 25(5): 439-442.

AZÉMA, J. \& TOURNON, J., 1980: La Péninsule de Santa Elena, Costa Rica: un massif ultrabasique charrié en marge pacifique de l'Amérique Centrale. - C. R. Académie Sciences Paris, 290: 9-12.

BAUMGARTNER, P.O., 1984: El complejo ofiolítico de Nicoya (Costa Rica): modelos estrucurales analizados en función de las edades de los radiolarios (Calloviense a Santoniense). In: Sprechmann P. (ed.): Manual de Geología de Costa Rica. - Editorial U.C.R.: 115-123.

BAUMGARTNER, P.O., MORA, C.R., BUTTERLIN, J., SIGAL, J., GLACON, G., AZÉMA, L. \& BOURGOIS, J., 1984: Sedimentación y paleogeografía del Cretácico y Cenozoico del littoral pacífico de Costa Rica. - Rev. Geol. América. Central, 1: 57-136.

BERMUDEZ, P.J., 1978, Un género nuevo de foraminífero de la familia Rotaliidae y otros géneros relacionados en la región CaribeAntillana. - Revista Española de Micropaleont. 10 (2): 192-204.

BOURGOIS, J., AZÉMA, J., BAUMGARTNER, P.O., TOURNON, J., DESMET, A. \& AUBOIN, J., 1984: The gologic history of the Caribbean-Cocos Plate boundary with special reference to the Nicoya Ophiolite Complex (Costa Rica) and D.S.D.P. results (Legs 67 and
84 of Guatemala): a synthesis. Tectonophysics, 108: 1-32.

CALVO, C., 1987: Las calizas nériticas de la vertiente pacífica del norte de Costa Rica y sur de Nicaragua: épocas y sistemas asociados con la apertura y evolución de la margen convergente de la América Central meridional. - 165 págs. Universidad de Costa Rica, San José [Thesis Lic].

CALVO, C., 1998: Kretazische Subduktionsprozesse in Südzentralamerika. - Profil, 15: $1-161$.

CALVO, C. \& BOLZ, A., 1991, La Formación Espíritu Santo (Costa Rica) : sistemas de plataforma carbonatada autoctona del Paleoceno Superior-Eoceno Inferior. - Rev. Geol. América Central, 13: 91-95.

CAUDRI, B., 1990: A note on the type material of the genus Ranikothalia (foraminifera.Eclogae-Geologicae Helvetiae, 83 (3): 747749.

CAUDRI, B., 1975: Geology and paleontology of Soldado rock, Trinidad (West Indies); Part 1, Geology and biostratigraphy. - Eclogae Geologicae Helvetiae, 68(3): 533-589.

DENGO, G., 1962: Estudio geológico de la región de Guanacaste, Costa Rica. - 112 págs. Inst. Geogr. Nac. San José.

DI MARCO, G., BAUMGARTNER, P.O. \& CHANNELL, J.E.T., 1995: Late CretaceousEarly Tertiary paleomagnetic data and a revised tectonostratigraphic subdivision of Costa Rica and western Panama. -Geol. Soc. America, Special Paper, 295: 1-27.

FERNÁNDEZ, J.A. (coordinador), 1997: Mapa Geológico de Costa Rica. - Escala 1: 750000. - Dirección de Geología y Minas, Dirección General de Hidrocarburos, San José. 
MASSIEUX, M. \& DENIZOT, M., 1964: Rapprochement du genre Pseudolithothamnium Pfender avec le genre actuel Ethelia Weber Van Bosse (Algues Florideae, Squamariaceae). - Revue Micropaléont. 7(1): 31-42.

M.I.E.M., 1982: Mapa geológico de Costa Rica (9 mapas). - Escala 1: 200 000. Inst. Geogr. Nac. San José.

MORA, C. \& BAUMGARTNER, P.O., 1985: Mapa geológico del sur de la península de Nicoya. - Escala 1: 50 000. Inst. Geogr. Nac. San José.

MORA, S., 1981: Barra Honda. - 94 págs. Ed. Univ. Estatal a Distancia, Serie Educación Ambiental 5, San José.

PFENDER, J., 1936: Sur un organisme constructeur des calcaires Crétacés et Nummulitiques, Pseudolithothamnium album, n.gr., nov. sp. . - Bull. Soc. Géol. France 5 (6): 303-308.

PFENDER, J. \& Schneegans, D., 1949: A propos de l'âge des calcaires des morros de San Juan (Etat de Guarico, Venezuela). - C. R. Soc. Géol. France, 1949: 91-93.

PRATURLON, A., 1966: Algal assemblages from Lias to Paleocene in Southern
Latium-Abruzzi: a review. - Bull. Soc. Geol. Italy, 85: 167-194.

RIVIER, F., 1983, Síntesis geológica y mapa geológico del área del Bajo Tempisque Guanacaste, Costa Rica. - Inf. Semestral Inst. Geogr. Nac. 1983: 7-30.

SCHMIDT-EFFING, R., 1975: El primer hallazgo de amonites en America Central Meridional y notas sobre las facies cretácicas en dicha región. - Inf. Semestral Inst. Geogr. Nac. 1975: 53-61.

SPRECHMANN, P., ASTORGA, A., BOLZ, A. \& CALVO, C., 1987: Estratigrafía del Cretácico de Costa Rica. - In: BARBARIN, J.M., GURSKY, , H.-J. \& MEIBURG, P. (eds.): El Cretácico de México y América Central. - Actas de la Facultad de Ciencias de la Tierra, U.A.N.L. Lineares- México, Resúmenes 2: 69-83.

TOURNON, J. \& ALVARADO, G.E., 1997: Mapa geológico de Costa Rica. - 77 págs. + mapa 1: 500 000. Ed. Tecnológica de Costa Rica, Cartago.

WINSEMANN, J., 1992: Tiefwasser-Sedimenta-tionprozesse und-produkte in den Forearc-Becken des mittelamerikanischen Inselbogensystems: Eine sequenzstratigraphische Analyse. - Profil, 2: 1- 218 [Thesis Ph.D.]. 